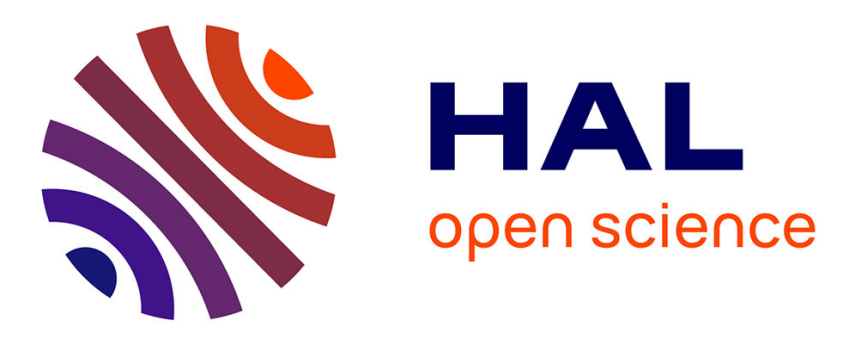

\title{
Actual share repurchases, timing and liquidity
}

Edith Ginglinger, Jacques Hamon

\section{To cite this version:}

Edith Ginglinger, Jacques Hamon. Actual share repurchases, timing and liquidity. Journal of Banking and Finance, 2007, 31 (3), pp.915-938. halshs-00136568

\section{HAL Id: halshs-00136568 \\ https://shs.hal.science/halshs-00136568}

Submitted on 25 Mar 2007

HAL is a multi-disciplinary open access archive for the deposit and dissemination of scientific research documents, whether they are published or not. The documents may come from teaching and research institutions in France or abroad, or from public or private research centers.
L'archive ouverte pluridisciplinaire HAL, est destinée au dépôt et à la diffusion de documents scientifiques de niveau recherche, publiés ou non, émanant des établissements d'enseignement et de recherche français ou étrangers, des laboratoires publics ou privés. 


\title{
Actual share repurchases, timing and liquidity
}

Edith Ginglinger and Jacques Hamon ${ }^{\mathrm{a}}$

May 2006

Key words: repurchase, timing, liquidity, Euronext Paris

JEL classification: G14, G32, G35

\begin{abstract}
Research on the impact of open market share repurchases has been hindered by the lack of data available on actual share repurchases in many countries, including the U.S. Using a previously unused database containing detailed information on 36,848 repurchases made by 352 French firms, we show that corporate share repurchases have a significant adverse effect on liquidity as measured by bid-ask spread or depth. Our results also indicate that share repurchases largely reflect contrarian trading rather than managerial timing ability.

${ }^{a}$ Both authors are from Cereg-DRM, Université Paris-Dauphine, place du Maréchal de Lattre, 75775 Paris cedex 16 - edith.ginglinger@dauphine.fr, jacques.hamon@dauphine.fr. We are grateful to Gérard Rameix for providing the data about daily repurchases. We thank Bruno Biais, François Degeorge, Thierry Foucault, Frederick Harris, Bertrand Jacquillat, Meziane Lasfer, Myron Slovin, Marie Sushka and two anonymous referees for their helpful comments and suggestions. All remaining errors are our own.
\end{abstract}




\section{Introduction}

Open market repurchases have become popular in recent years in a large number of countries. Dittmar and Dittmar (2002) report that repurchases in the United States accounted for $44.42 \%$ of total payouts in 2000 compared to $11.82 \%$ of payouts in 1971 . Increased repurchase activity has also been documented for Canada and the U.K. Countries where stock buybacks were previously prohibited, such as Germany or Taiwan, now allow firms to repurchase their shares on the open market. In France, open market stock repurchase programs have increased sharply since a 1998 law introduced provisions simplifying their implementation. Prior work has considered valuation effects at announcements of open market repurchases (Vermaelen, 1981), the choice between dividends and repurchases (Grullon and Michaely, 2002), the reasons why firms repurchase (Dittmar, 2000), the information content of buyback announcements (Grullon and Michaely, 2004), and the longterm performance of repurchasing firms (Ikenberry, Lakonishok and Vermaelen, 1995). There is less work and considerable ambiguity about the impact of corporate share repurchases on stock liquidity. Barclay and Smith (1988) find that repurchases have a negative impact on liquidity, Miller and McConnell (1995) find no evidence of an increase in bid-ask spreads surrounding announcements of repurchase programs, and Wiggins (1994) and Singh, Zaman and Krishnamurti (1994) report a decline in bid-ask spreads.

Since companies that announce share repurchase programs are under no obligation to carry them out, the proportion of repurchases that are actually undertaken is a prerequisite to gaining meaningful insight into repurchase decisions. However, this data requirement is rarely met, since actual repurchases, especially the dates of trades, are not available for most countries. In the U.S. it is difficult to study actual share repurchases since firms can repurchase shares without making announcements, and can announce repurchase programs without executing them, given that the only disclosure requirement is a statement of the number of shares outstanding at quarter-end. Thus, share repurchases in the U.S. cannot be observed at the time of the transaction nor directly measured afterward. Previous studies have adopted two approaches to circumvent this difficulty. Stephens and Weisbach (1998) use the quarterly decrease in the firm's shares outstanding as a proxy for the number of shares repurchased. However, this approach understates the true number of shares repurchased if a firm grants shares to employees or stock options are exercised, and provides little information about the implementation of open market repurchase programs or the impact of repurchases 
on liquidity, since transaction dates are not known. Cook, Krigman and Leach (2004) use voluntarily disclosed data for 64 firms' repurchase programs during the period 1993 and 1994.

An alternative approach is to analyze firms listed on stock exchanges that require disclosure about share repurchases. Brockman and Chung (2001) study the effect of managerial trading on liquidity, using data for firms listed on the Hong Kong Stock Exchange, which requires disclosure of repurchases by the following business day. Zhang (2005) investigates share price performance surrounding actual share repurchases on the Hong Kong market.

In this paper, we use data from Euronext Paris (the Paris Stock Exchange) to study the timing of actual repurchases and their impact on liquidity, given that listed firms must disclose data about repurchases for a given month at the beginning of the following month. We also obtain precise trading dates for repurchases from the Autorité des Marchés Financiers (AMF) ${ }^{1}$ database, for 36,848 firm-trading days for the period 2000 through 2002, a sample size that greatly exceeds that used in prior studies of actual repurchases.

First, we assess whether buybacks are motivated by price support objectives or the opportunity to profit from private information. Brockman and Chung (2001) conclude that managers acquire shares at lower cost than a naïve accumulation strategy, but their findings are also consistent with either opportune timing based on insider information or price support. Zhang (2005) finds that firms repurchase shares after a 20-day period of negative share price performance, that the short-term market response to actual share repurchases is significantly positive, and that subsequent 20-day period share price performance is positive but only weakly significant. We find that companies repurchase shares following periods when the share price has been falling, evidence that companies purchase against market trends, but find no significant rise in share prices afterward. Thus, our results are consistent with the price support hypothesis.

Second, we analyze the effect of repurchases on different measures of market liquidity. We examine two competing hypotheses. One hypothesis is that liquidity is enhanced when management buys back shares by entering limit orders in the order book. The competing hypothesis is that liquidity deteriorates on repurchase days due to either trading on private information or contrarian trading. Prior studies of actual repurchases report conflicting results for the effects on liquidity. For the Hong Kong Stock Exchange, Brockman and Chung (2001) find that liquidity deteriorates during repurchase periods. However, Cook, Krigman and Leach (2004) show that repurchases in the U.S. enhance firm liquidity by narrowing the bid- 
ask spread on days when repurchase trades are completed. Our study compares trading days when repurchase trades are executed to trading days surrounding non-repurchase days. We examine changes in the effective relative bid-ask spread and depth on the date of repurchase trading, and find a highly significant reduction in liquidity, a result that applies to all market segments.

Our results are broadly consistent with Brockman and Chung (2001), who conclude that managers' trade on private information. However, we argue that managers mainly adopt contrarian trading that reflects the heterogeneity of expectations in the market. Such repurchases increase asymmetric information, which in turn increases the bid-ask spread. Overall, repurchases are large enough to stabilize prices, but do not lead to a higher share price. Despite differences between disclosure regulations in France and Hong Kong, we find that the two markets produce broadly similar results. Some market participants, for example proprietary trading desks, may be trading based on their knowledge of order flow for a stock. Even if they do not surmise that it is the firm itself that is repurchasing shares, they could suspect an informed trader. Thus, our results are not consistent with the conclusions of Cook, Krigman and Leach (2004), who argue that differences in disclosure regulations between the U.S. and Hong Kong can explain the divergence between their results and those of Brockman and Chung (2001).

The remainder of the paper is organized as follows. In Section 2, hypotheses related to timing and liquidity effects of corporate repurchases are developed. In Section 3, the structure and repurchase disclosure environment of the Paris Stock Exchange is described, and in Section 4, data are discussed. In Section 5, empirical results are reported. Conclusions are provided in Section 6.

\section{Timing and liquidity hypotheses}

\subsection{Timing versus price support hypotheses}

The dominant explanation for share repurchases is the information-signaling hypothesis which explains repurchases as a means to signal managers' belief that the firm's stock is undervalued (Vermaelen, 1981)). Stephens and Weisbach (1998) report negative abnormal returns prior to repurchase announcements, indicating that firms repurchase when 
managers perceive their shares as undervalued. Ikenberry, Lakonishok and Vermaelen (1995) find negative share price performance before a repurchase announcement, followed by a period of abnormal positive performance. However, these authors did not have access to the dates of actual repurchases, and thus are unable to verify whether managers have timing ability. Brockman and Chung (2001) use a bootstrapping technique in their study of the Hong Kong market. They construct empirical distributions of repurchase costs and compare them to actual costs, finding that bootstrapped costs significantly exceed actual costs, results that are consistent with managerial timing ability. Cook, Krigman and Leach (2004) find that NYSE firms exhibit some timing ability, since acquisition costs are lower than various benchmarks, but Nasdaq firms do not on average beat their benchmarks. They document that firms repurchase shares following declines in their stock prices and that prices stabilize following repurchases, evidence that suggests firms repurchase to trade against the trend to support prices in a depressed market.

We use data from the Paris stock exchange to determine whether the motivation for repurchases is market timing or price support. The market-timing hypothesis implies that the firm's share price should be lower on repurchase days than on subsequent non-repurchase days. The price support hypothesis implies that a firm's share price should be lower on repurchase days than on prior non-repurchase days, but not significantly different from subsequent non-repurchase days. We discriminate between these hypotheses by examining relative prices for repurchase days compared to non repurchase days, using both raw ratios and market-adjusted ratios.

\subsection{Liquidity hypotheses}

The two prior studies that examine the liquidity effects of actual repurchases report conflicting results. Brockman and Chung (2001) find that liquidity deteriorates during repurchase periods at the Hong Kong Stock Exchange, while Cook, Krigman and Leach (2004) find that in the U.S. repurchases enhance liquidity by narrowing the bid-ask spread and attenuating the price impact of order imbalances on days when repurchase trades are completed.

We consider two alternative predictions. One prediction is that liquidity is enhanced when management repurchases shares by entering limit orders in the order book, implying a decrease in the bid-ask spread and an increase in depth. A second prediction is that liquidity is reduced when management repurchases shares, which is consistent with both the market- 
timing hypothesis and the price support hypothesis. Theories of market-timing assume managers have an informational advantage over other investors and trade on it. The presence of a better-informed trader leads to a widening of the bid-ask spread, thereby increasing transaction costs for all investors and reducing liquidity. According to the price support hypothesis, managers trade against the trend to support the firm's share price in a depressed market. It may be that some repurchases are carried out aggressively, with the trades taking place at the ask, reducing the depth for sellers in the central order book. Thus, the bid ask spread would widen due to an increase of asymmetric information resulting from the heterogeneity of expectations in the market.

\section{The French disclosure environment and market structure}

\subsection{Repurchase disclosure environment}

Pursuant to the July 2, 1998 law, open market stock repurchases are authorized up to the limit of $10 \%$ of a firm's capital and can extend for a maximum period of 18 months. The objectives and terms of open market stock repurchase are defined at the annual shareholder meeting. For each 24-month period, subject to shareholder authorization, shares representing up to $10 \%$ of a firm's existing capital can be cancelled. Firms can also use the acquired shares to grant shares or options to employees, stabilize stock prices, exchange stock as part of a merger or acquisition, reduce or eliminate dilution related to conversion of convertible bonds, or hold the shares as treasury stock. Once a French company's repurchase program is approved, a registration statement is issued to obtain approval by the AMF. No subsequent announcement is necessary before the company can proceed with actual repurchases.

In the U.S., the only regulatory guide for executing open market repurchases is the SEC's "safe harbor" Rule 10b-18, which describes a code of conduct that, if followed, protects the corporation against charges of share price manipulation. It is commonly believed that the safe harbor rule is followed by most repurchasing firms (Cook, Krigman and Leach, 2003). Although French regulations are broadly similar to those in the U.S., there are some differences. In France, purchases and bids must be executed through a single broker or dealer on any given day and repurchases are prohibited at the opening and closing call auctions on the continuous market. Non-block purchases for any given day must not exceed $25 \%$ of the 
standard trading volume specified for the relevant security. ${ }^{2}$ The purchase price must fall within the lowest-highest price interval for the elapsed portion of the relevant trading day.

There are two important differences between U.S. and French regulations. One difference concerns the reselling of shares that are acquired through a repurchase program. In the U.S., these shares cannot be resold, so that firms follow a strategy of pure accumulation, and the shares acquired are later cancelled or granted to employees when stock options are exercised. In France, however, repurchased shares can be freely resold, facilitating market timing. A second difference concerns disclosure. Each month, French firms are required to publicly report the total number of shares repurchased or sold during the previous month. These disclosure regulations are in contrast to those of the U.S. and Hong Kong. Until 2004, the U.S. had no disclosure requirement. In Hong Kong, shares repurchased on a given day must be reported before the start of trading on the following business day. Thus, France represents an intermediate disclosure environment that can provide valuable insight into the impact of repurchase disclosure.

Evidence from the French market provides a framework for assessing the consequences of recent changes to U.S. regulations. In December 2003, the Securities and Exchange Commission adopted several amendments to Rule 10b-18, to enhance the transparency of repurchases. The amendments require disclosure of all issuer repurchases of equity securities for the previous fiscal quarter, including the total number of shares purchased (reported monthly) and the average price paid per share. Thus, since 2004, the disclosure of information concerning repurchases by U.S. companies has been similar to French practices.

Although monthly disclosed data are useful, they are not sufficiently detailed for the purposes of this study since they lack information about trading dates. In contrast, French firms are required to report precise trading dates to the AMF. Although this information is not public, we were granted access to it for the purpose of this study. The AMF collects a $0.15 \%$ tax calculated by multiplying the number of shares repurchased by the weighted average price of the repurchases. Since sales are not subject to this tax, no sales-related information is included in the database. Our work therefore analyzes only share purchases. However, using published monthly sales data, we can verify that, on average, resales comprise less than one fifth of the amount of securities repurchased. For robustness, we also tested subsamples of companies that purchased shares but sold no shares over the period of our analysis. The results are similar to the full sample, and thus are not reported in the tables. 


\subsection{Euronext Paris market structure}

Euronext Paris is an electronic limit order market. There are two main market models: continuous trading for the more actively traded stocks, and a double auctions market for the less liquid stocks. A further description of these models can be found in Biais, Hillion, and Spatt (1999). A call auction determines the opening and closing price in the continuous market where trading takes place from 9:00 a.m. to 5:25 p.m. Traders mainly use limit orders and market orders. The tick size varies from $0.01 €$ for share prices under $50 €$ to $0.5 €$ for share prices over $500 €$.

Deferred settlement is possible for a subset of the more liquid shares. This market segment is called the SRD (service à réglement différé). For all other shares, only cash trading is possible. All SRD stocks belong to the continuous market and account for approximately $89 \%$ of the total market value of Euronext Paris. In several cases, we report results in three categories, according to the type of trading and market model: SRD, cash market continuous trading, and cash market - auction trading.

Euronext Paris offers substantial transparency. The five best bid/ask limits (price and quantity) in the order book are publicly released and members have access to all orders outstanding in the book, although the identity of the broker is not shown. Traders can also submit iceberg orders (also referred to as hidden-size orders). For these orders, only specified tranches are successively entered in the order book, and disclosed to the market with the current time stamp, after full execution of the preceding tranche.

Over the period of our study, transactions on the regulated block trade market are available for only a small number of firms. Shares listed on the auction market, for example, were not eligible. ${ }^{3}$ Trades of more than the normal block amount (NBA), as defined by Euronext, can be executed through either the Central Order Book or the block trade facility. For the period of our study, the NBA, which is established for each firm and revised quarterly, corresponds approximately to the quantity of shares in the order book for the five best price limits. The NBA varies in both quantity and value across stocks. An ordinary block could be traded on the block trading facility within a price range extended to approximately the weighted average price of the five best price limits. Most transactions, even very large trades, are executed through the Central Order Book rather than block trading facilities. ${ }^{4}$ Offhours transactions are also possible for all shares. Transactions made outside the trading hours are executed at a price within a range of $1 \%$ around the last transaction price. 


\section{Data}

We use the Euronext intraday database, which contains a time-stamped record of all transactions and orders submitted to the market from January 2000 through December 2002 for 918 French firms. These data include transaction prices, volumes, and the best limits of the order book (bid and ask prices, and bid and ask size), as well as market capitalization. All data are stamped to the nearest second.

We also use data from the AMF, which provides the actual daily repurchases for all firms listed on the Paris Exchange from January 2000 through December 2002. The data include the name of the repurchasing company, the date, the number of shares repurchased, the share price, and the daily total value of repurchases. In some cases, a breakdown of all buyback transactions for a given day is reported, while in other cases only a weighted average price for the day is reported. On the whole, even when a detailed breakdown is available, it is difficult to locate the exact transaction in the database that corresponds to a particular buyback. On the SRD market, the average number of separate transactions during a day, including repurchases, is $970 .^{5}$ Therefore, we focus our work on the daily weighted average repurchase price.

In Table 1, descriptive statistics are reported for the 371 repurchasing firms (at least one trading day involving a repurchase over the three years) and the 547 non-repurchasing firms (no repurchase over the three years). During the sample period, 40.41\% of Paris-listed firms repurchased shares.

\section{[Insert Table 1 here]}

Repurchasing firms are significantly larger than non-repurchasing firms (average market capitalization is more than four times greater). The average daily rates of return are comparable for both categories of firms. The average effective relative spread for repurchasing firms, $2.31 \%$, is significantly lower than for non-repurchasing firms, $4.32 \%$. Turnover is higher for the repurchasing firms. Depth is not significantly different between the two groups, while share volatility (whether measured daily, hourly or quarter-hourly) is lower for repurchasing firms. The data confirm that repurchasing firms have greater liquidity than non-repurchasing firms. The average number of daily transactions is 127 for firms that did not conduct repurchases compared to 337 for firms that repurchased shares. In general, the descriptive statistics indicate that the companies repurchasing shares are the largest and most liquid firms. 


\section{Empirical results}

Our results encompass a description of the main characteristics of share repurchases, tests of managerial timing ability, and an analysis of the impact of repurchases on liquidity.

\subsection{The repurchase decision}

Table 2 provides summary statistics for all repurchasing companies included in the sample. To be retained in the final sample, we require that there be a precise date reported for the repurchase, that the reported repurchase price is higher than the minimum and lower than the maximum trading price that day, and that the quantity repurchased is lower than the total quantity traded on the exchange. The final sample consists of 352 firms and 36,848 repurchase trading days over the 36-month period of study.

\section{[Insert Table 2 here]}

On average, sample firms repurchase shares with a value of $1.78 \%$ of their market capitalization. The average number of shares repurchased in a single trading day is 12,495 for all firms, 40,532 for firms listed on the SRD market (continuous market with deferred settlement facilities) and 262 for firms listed on the auction market. Firms listed on the Paris Exchange repurchase a total of 460.4 million shares with a total value of 33.9 billion $€$. The most active repurchase firms trade on the SRD market, purchasing 33.3 billion $€$ of shares, or $98.11 \%$ of the total repurchases. The average repurchase accounts for $27.90 \%$ of the total value of traded shares on the transaction date. Repurchases take place on $20.21 \%$ of firmtrading days, but repurchase frequency varies widely. Some firms spread their repurchases over several months, while others conduct only a few transactions. The average number of repurchase days per firm is 95.7. On average, firms listed on the SRD repurchase on 85.9 days, and firms on the auction market (cash-only continuous market) repurchase on 62.2 days (119.5 days).

\subsection{Managerial timing and private information}

We discriminate between the private information and the price support hypotheses by examining share prices around repurchases. First, we utilize univariate tests (Table 3). We compute the value-weighted average price (Vwap) as the average price of all transactions 
through the central order book, weighted according to the proportional value of the transaction in the trading day. ${ }^{6}$ We use several relative prices for our tests. We compute the raw ratios of the Vwap for each trading day to the average Vwap over a two-, four- and sixmonth period (beginning 1, 2, or 3 months before, and ending 1, 2, or 3 months after the day concerned, excluding repurchase days). We also calculate comparable market-adjusted ratios, equal to the previous ratios divided by the same ratios over the same periods, using the SBF250 index. The timing and price support hypotheses each predict that both raw and market-adjusted ratios should be lower for days with repurchases than for days with no repurchases.

We consider two other classes of ratios: the Vwap for each day relative to the average Vwap over the preceding one, two or three months, or over the subsequent one, two or three months (excluding repurchase days). Both raw and market-adjusted ratios are reported. The market-timing hypothesis contends that managers buy stock when they possess more favorable information than when they do not buy stock, implying that the Vwap/(Vwap $n$ monthsafter) ratio for repurchase days should be lower than the same ratio for non-repurchase days. The price support hypothesis contends that managers repurchase stock after a price drop, even though they have no private information about future price developments. Thus, the Vwap/(Vwap n months before) ratio for repurchase days should be lower than the same ratio for non-repurchase days, while the Vwap/(Vwap $n$ monthsafter) ratio should not be significantly different from repurchase days.

We find that the average Vwap/(Vwap 2n months) raw ratio is significantly lower on repurchase days (by $1.2 \%, 1.45 \%$ and $1.68 \%$ for $n=1,2,3$ respectively and for the full sample). This effect is more pronounced for SRD shares than for the cash-only market. When market adjustments are taken into account, the results are less pronounced but remain highly significant. These findings are consistent with both the timing and price support hypotheses. ${ }^{7}$

We find that the average Vwap/(Vwap $n$ months before) is significantly lower for repurchase days. For example, for the full sample (SRD market firms) the average differential is $2.83 \%(3.12 \%)$ for repurchase days compared to non-repurchase days for $n=3$. For cashonly market firms, the differential is $2.71 \%$. The equivalent market-adjusted ratios are also significantly lower on repurchase days; for three months, the differential is $1.33 \%$ for the full sample, $1.52 \%$ for SRD firms, and 1.29 for the cash-only market.

The raw Vwap/Vwap n months after ratio is also lower on repurchase days but only by $0.3 \%$ on average for $\mathrm{n}=3$, with a lower significance level. Further, the market-adjusted Vwap/(Vwap n months after) ratio is not significantly different on repurchase days, regardless 
of period and market. While these findings are not sufficient to fully dismiss the presence of managerial timing, the results are more consistent with the price support hypothesis. ${ }^{8}$ Over the medium term (one, two or three months), companies mainly repurchase shares after the relative share price has fallen. The impact of any private information is limited, and disappears when market-adjusted ratios are considered.

\section{[Insert Table 3 here]}

We also observe the price trend during the repurchase day, as well as for the trading days from two days immediately before to five days immediately after the repurchase. If managerial actions are motivated by price support, repurchases would be expected to occur on trading days when prices are falling, and/or immediately after a fall in price. By comparison, if managers are exercising timing skills, we would expect to observe rising price trends in the trading days after the repurchase day.

Rates of return are measured based on midpoints, so as to eliminate any effects due to market microstructure (e.g. bid-ask bounces). The rate of return for a given trading day is calculated from that day's opening to the next day's opening. A more detailed analysis is provided for the repurchase day and the preceding day. The rate of return for the day prior to a repurchase transaction is separated into two components: one, the rate observed from the first to the last transaction price, and two, the rate observed off-hours, that is from the last transaction price to the first transaction price of the repurchase day. Three rates of return are calculated for the repurchase day: the change in price from the opening to the repurchase, the change from the repurchase to the close of trade, and the change from the close to the next day's opening. The repurchase price may be from a single transaction, or a weighted average of several transactions. These results are compared with rates of return when no repurchase takes place. For non-repurchase days, the rate of return breakdown is limited to the rate of return for trading hours (open to close), and the off-hours rate of return (from the close to the next day's opening). The results are reported in Table 4 for the full sample and for subsamples by market type. ${ }^{9}$

\section{[Insert Table 4 here]}

For the full sample, we find that repurchases occur after a fall in price over the previous two trading days. The average midquote rate of return measured from the preceding close to the open is $-0.132 \%$ for repurchase days versus a positive return of $0.121 \%$ for days 
with no repurchases. Similar results are obtained for all markets. The fall in price accelerates during the repurchase day. For the full sample, the average midquote rate of return during trading hours is $-0.287 \%(-0.022 \%)$ for repurchase (non-repurchase) trading days. Dividing the day into sections, the rate of return from the open to the repurchase is $-0.331 \%$ for the full sample $(-0.606 \%$ for SRD stocks and $-0.216 \%$ for the others). After the repurchase, on average, there is a rise of $0.076 \%$ for the full sample, and a rise of $0.237 \%$ for SRD market companies. For the five days after a repurchase, the price trends are not significantly different from when no repurchase occurs, regardless of market. Analysis based on medians displays the same overall pattern.

Our evidence suggests that firms act against market trends, executing their purchases to take advantage of falling prices, a result consistent with a price stabilization motive for repurchases. The results are particularly significant for stocks listed on the SRD market. Since companies do not appear, in the short term, to repurchase stock just before prices rise, our results are consistent with the price support hypothesis rather than the market timing hypothesis.

\subsection{Liquidity effects}

A repurchase program can affect a firm's stock liquidity in two opposing ways. Repurchase trading can increase liquidity on the bid side, enhancing share liquidity, but also may reduce share liquidity because of the possibility of trading by an informed trader or a firm's contrarian trading strategy. We discriminate between these two effects by using univariate and then multivariate evidence.

We conduct an in-depth analysis of the bid-ask spread around repurchase days. Table 5 compares the daily average (median) spreads for repurchase days with spreads for three benchmark days. A lag (lead) benchmark corresponds to the day before (after) the repurchase day when no repurchase takes place. The last benchmark corresponds to a four-week period before the repurchase, after eliminating any repurchase days during the period.

For the full sample, the average first available (daily average) spread on repurchase days is $2.4 \%(2.08 \%)$, which is $0.07 \%(0.06 \%)$ higher than the previous day's average spread, and $0.14 \%(0.11 \%)$ higher than the spread for the four weeks preceding the repurchase. For companies listed on the SRD market (cash-only market), the daily average spread ${ }^{10}$ is $0.55 \%$ $(2.73 \%)$ on repurchase days, compared to $0.51 \%(2.53 \%)$ for the day before the repurchase and $0.53 \%(2.60 \%)$ for the following day. The average spread over the four weeks prior to the 
repurchase is $0.83 \%(2.55 \%)$. The average spreads on repurchase days are significantly greater than the prior-period benchmarks (lag day and pre-repurchase period) for both samples, whereas they are significantly different from the lead day benchmark only for the firms listed on the cash-only market. Overall, these results support the hypothesis that a firm's share liquidity is reduced when it undertakes share repurchases.

[Insert Table 5 here]

To complement the univariate analysis, we estimate several regression models. Table 6 reports the estimation results from the following regression model.

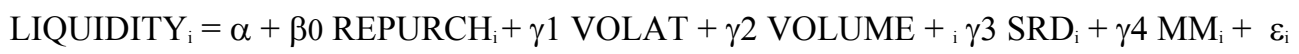

\section{[Insert Table 6 here]}

Liquidity $_{i}$ is the dependent variable represented by either the relative spread or the depth for the firm-day i. ${ }^{11}$ We log-transform the variable depth because of skewness in its distribution. We specify four control variables. The cost components of the bid-ask spread fall into three categories: order-processing costs, inventory-holding costs, and adverse selection costs. Since order-processing costs are largely fixed, the bid-ask spread should decrease with trading volume. A market maker incurs inventory-holding costs when providing liquidity. In an order-driven market, limit order traders run the risk of non-execution, and inventory costs grow as volatility rises. Thus, the bid-ask spread should increase with volatility. Adverse selection costs result from the risk of trading with individuals who possess private information. Several measures of adverse selection costs have been used in the literature. Specifically, the bid-ask spread should increase with insider ownership (Glosten and Harris, 1988) and with volatility (Copeland and Galai, 1983), while it should decrease with the size of the firm (market value) and trading volume. ${ }^{12}$

To take account of the combined effects of control variables suggested by previous studies of the determinants of the bid-ask spread, we introduce a volatility variable (average annualized estimate of daily volatility over the prior 21 trading days) ${ }^{13}$, as suggested by Stoll (1978) and Harris (1994), and a trading volume variable (log of the daily turnover in euros). We also use two dichotomous variables corresponding to settlement method and market model. Variable SRD equals one when shares are continuously quoted and have deferred settlement facilities, 
and zero otherwise. Variable MM equals one when shares are quoted on the auction market, and zero otherwise. These variables correspond to different market capitalizations and trading volumes. Repurchasing activities are accounted for by a dummy variable, REPURCH, that equals one when the firm repurchases shares during a given day, and zero otherwise.

Liquidity, regardless of measure, increases with trading volume, and is greater for firms on the SRD market and lower for firms on the auction market. Liquidity decreases as volatility for the 21-day period preceding the trade increases. This result is consistent with previous findings on the determinants of the bid-ask spread.

Our results indicate that relative spread increases and depth decreases on days when repurchases take place. These findings are robust, since they are independent of trading or settlement method. Liquidity falls when the firm repurchases its own shares in any market. ${ }^{14}$ For the relative spread averaged over a trading day, there is a 0.0021 to 0.0026 increase on repurchase days, depending on the model. Thus, our results support the hypothesis that information asymmetry increases when the firm repurchases its own shares.

Overall, we conclude that repurchase orders are large enough to stabilize prices and reduce liquidity, but are not followed by an increase in share price. Our results imply that the deterioration in liquidity on repurchase days in France is similar to the effect observed in Hong Kong, although the disclosure deadlines differ between the two markets. Thus, it is unlikely that the divergence between the results reported for the U.S. and Hong Kong can be attributed to differences in disclosure regulations and practices.

Our findings also contribute to a debate that began in the U.S. in December 2002 about compulsory disclosure of information as to when repurchases actually take place. Since the new U.S. disclosure regulations that were adopted in December 2003 closely resemble French practices, it should eventually be feasible to determine whether the differences in the results reported in the literature can be attributed to differences in disclosure requirements or to other factors, such as differences in the way the markets operate.

\section{Conclusion}

Our study of actual share repurchases in France contributes to an understanding of the impact of open market share repurchases on stock markets. Following the 1998 reform of French regulations governing share repurchases, there has been a wave of large-scale corporate share repurchases on the French stock market. We study a large sample of actual 
share repurchases in France by obtaining access to a proprietary database. Within this context, we evaluate both the validity of the managerial timing ability hypothesis and the impact of repurchases on liquidity. We use a sample of 352 firms that repurchase shares over a three years period, with corresponding time-stamped data, the largest sample used to date. A lack of comparable disclosure information makes this type of analysis impossible in the U.S. French firms must disclose all repurchases in a given month at the start of the following month, a constraint that falls between the non-disclosure that applied in the U.S. before 2004 and the next-day disclosure compulsory in Hong Kong.

On average, French firms repurchase shares at a price lower than that paid by other investors since shares are repurchased after an observable decline in share price. Our results provide little evidence to support the theory that managers use private information to repurchase stock before the share price rises.

Regardless of trading method, repurchases significantly reduce the liquidity of the market for relevant shares. This reduction in liquidity has also been reported for the Hong Kong market, but not for the U.S. market. This divergence from U.S. results may be due either to the lack of data on actual repurchases for the U.S. prior to 2004 or to differences in disclosure regulation. The similarity of our results to the results for the Hong Kong market indicates that the choice of whether to require firms to disclose repurchases one day versus one month after execution does not affect the impact of share repurchases on liquidity. Thus, our results suggest that there are limited benefits from requiring greater post-trade transparency of share repurchases. 


\section{References}

Barclay, M. J., Smith, C.W., 1988. Corporate payout policy: cash dividends versus openmarket repurchases. Journal of Financial Economics 22, 61-82.

Biais, B., Hillion P., Spatt, C., 1999. Price discovery and learning during the preopening period of the Paris Bourse. Journal of Political Economy 107, 1218-1248.

Bollen, N., Smith T., Whaley R., 2003. Modeling the bid/ask spread: measuring the inventory-holding premium. Journal of Financial Economics 72, 97-141.

Brockman, P., Chung, D.Y., 2001. Managerial timing and corporate liquidity: evidence from actual share repurchases. Journal of Financial Economics 61, 417-448.

Cook, D.O., Krigman L., Leach J.C., 2003. An analysis of SEC guidelines for executing open market repurchases. Journal of Business 76, 289-316.

Cook, D.O., Krigman L., Leach J.C., 2004. On the timing and execution of open market repurchases. Review of Financial Studies 17, 463-498.

Copeland, T. E., Galai, D., 1983. Information effects of the bid-ask spread. Journal of Finance $38,1457-1469$.

Dittmar, A. K., 2000. Why do firms repurchase stock? Journal of Business 73, 321-356.

Dittmar, A. K., Dittmar R., 2002. Stock Repurchase Waves: An Explanation of the Trends in Aggregate Corporate Payout Policy? Working paper, Indiana University

Glosten, L. R., Harris L.E., 1988. Estimating the components of the bid-ask spread. Journal of Financial Economics 21, 123-142.

Grullon, G., Michaely R., 2002. Dividends, share repurchases and the substitution hypothesis. Journal of Finance 57, 1649-1684.

Grullon, G., Michaely R., 2004. The information content of share repurchase programs. Journal of Finance 59, 651-680.

Harris, L. E., 1994. Minimum price variations, discrete bid-ask spreads, and quotation sizes. Review of Financial Studies 7, 149-178.

Ikenberry, D., Lakonishok J., Vermaelen T., 1995. Market underreaction to open market share repurchases. Journal of Financial Economics 39, 181-208.

Miller, J. M., McConnell J., 1995. Open-market share repurchase programs and bid-ask spreads on the NYSE: implications for corporate payout policy. Journal of Financial and Quantitative Analysis 30, 365-382. 
Singh, A. K., Zaman M.A., Krishnamurti C., 1994. Liquidity changes associated with open market repurchases. Financial Management 23, 47-55.

Stephens, C. P., Weisbach M., 1998. Actual share reacquisitions in open-market repurchase programs. Journal of Finance 53, 313-333.

Stoll, H. R., 1978. The pricing of dealer services: an empirical study of NASDAQ stocks. Journal of Finance 33, 1153-1172.

Stoll, H. R., 2003. Market microstructure. In Constantinides, G., Harris, M. Stulz, R. (Eds.), Handbook of the Economics of Finance. North-Holland, Amsterdam.

Vermaelen, T., 1981. Common stock repurchases and market signalling: an empirical study. Journal of Financial Economics 9, 138-183.

Wiggins, J. B., 1994. Open market stock repurchase programs and liquidity. Journal of Financial Research 17, 217-229.

Zhang, H., 2005. Share price performance following actual share repurchases. Journal of Banking and Finance 29, 1887-1901. 
Table 1

\section{Descriptive statistics of Paris listed firms}

This table contains all the shares and similar securities listed in Paris on the regulated Euronext markets from January 2000 through December 2002 , including those newly listed or delisted during the period. Shares for which there were no repurchases over the period are classified under "No repurchase" while those for which there was at least one repurchase transaction are classified under "Repurchase". The averages of all daily observations are shown in the table. The total number of shares is 918 . The number of observations (column $\mathrm{N}$ ) corresponds to the number of firm-trading days available. The last columns provide parametric and non-parametric tests to compare firms that repurchased at least once and firms that did not repurchase; * indicates statistical significance at the $1 \%$ level.

\begin{tabular}{|c|c|c|c|c|c|c|c|c|}
\hline & \multicolumn{3}{|c|}{ No repurchase } & \multicolumn{3}{|c|}{ Repurchase } & \multirow[b]{2}{*}{$\begin{array}{l}\mathrm{T}- \\
\text { Statistics }\end{array}$} & \multirow[b]{2}{*}{$\begin{array}{l}\text { Z- } \\
\text { Statistics }\end{array}$} \\
\hline & Mean & Median & $\mathrm{N}$ & Mean & Median & $\mathrm{N}$ & & \\
\hline Market capitalization (in million $€$ ) & 703.1 & 49.7 & 268,200 & $3,148.0$ & 183.7 & 253,531 & $-102.44 *$ & $190.61^{*}$ \\
\hline Value weighted average price (central order book), (in $€$ ) & 57.07 & 18.05 & 268,234 & 76.75 & 41.46 & 252,317 & $-24.82 *$ & $169.53 *$ \\
\hline Rate of return (open to close) & $0.022 \%$ & $0.000 \%$ & 246,695 & $0.029 \%$ & $0.000 \%$ & 248,322 & -0.77 & $-2.99 *$ \\
\hline Rate of return (midquote open to close) & $0.024 \%$ & $0.000 \%$ & 231,376 & $-0.084 \%$ & $0.000 \%$ & 241,074 & 0.77 & $3.20 *$ \\
\hline Rate of return (preceding close to open) & $-0.039 \%$ & $0.000 \%$ & 246,695 & $-0.041 \%$ & $0.000 \%$ & 248,322 & 0.24 & 1.66 \\
\hline Rate of return (midquote preceding close to open) & $0.069 \%$ & $0.000 \%$ & 230,542 & $0.060 \%$ & $0.000 \%$ & 240,742 & 1.09 & $-5.82 *$ \\
\hline Relative spread (average at opening) & $4.32 \%$ & $2.36 \%$ & 244,439 & $2.31 \%$ & $1.28 \%$ & 243,735 & $144.32 *$ & $-131.23 *$ \\
\hline Turnover (central order book daily average in $€$ ) & $2,168,135$ & 11,451 & 268,234 & $9,543,192$ & 57,268 & 253,538 & $-75.53 *$ & $157.02 *$ \\
\hline Depth (central order book daily average at opening in $€$ ) & 137,331 & 5,597 & 254,119 & 171,178 & 9,230 & 249,042 & -1.88 & $120.28 *$ \\
\hline Volatility (average annualized daily estimation) & $65.81 \%$ & $52.70 \%$ & 262,442 & $48.80 \%$ & $40.22 \%$ & 252,870 & $56.33^{*}$ & $-123.50 *$ \\
\hline Number of observations in daily volatility figure $(\max =21)$ & 18.3 & 21.0 & 268,233 & 20.2 & 21.0 & 253,538 & $-164.44 *$ & $134.50 *$ \\
\hline Volatility (average annualized hourly estimation) & $107.72 \%$ & $79.64 \%$ & 148,868 & $72.61 \%$ & $54.00 \%$ & 203,066 & $65.55^{*}$ & $122.16^{*}$ \\
\hline Number of observations in hourly volatility figure $(\max =36)$ & 11.7 & 6.0 & 268,233 & 18.9 & 18.0 & 253,538 & $-188.30 *$ & $154.42 *$ \\
\hline Volatility (average annualized quarter hourly estimation) & $143.05 \%$ & $96.34 \%$ & 113,101 & $96.27 \%$ & $62.45 \%$ & 161,797 & $73.50 *$ & $98.39 *$ \\
\hline Number of observations in quarter hourly volatility figure $(\max =36)$ & 5.8 & 1.0 & 268,233 & 11.2 & 4.0 & 253,538 & $-166.16^{*}$ & $158.50 *$ \\
\hline Number of transactions (daily average) & 127 & 8 & 268,234 & 337 & 21 & 253,538 & $-82.06^{*}$ & $131.47 *$ \\
\hline
\end{tabular}


Table 2

Characteristics of repurchasing firms

The sample consists of 352 firms listed on the Paris market that repurchased their own shares during at least one trading day between January 2000 and December 2002 . The sample is divided into three subgroups according to settlement method (cash-only or with deferred settlement facilities) and the market model (continuous trading or auction trading). The sum of the number of shares in the three subpanels is higher than 352 since some shares change market type during the period.

\begin{tabular}{|c|c|c|c|c|c|}
\hline & \multirow[t]{2}{*}{ All shares } & \multirow{2}{*}{$\begin{array}{c}\text { SRD } \\
\text { (deferred settlement) } \\
\text { shares }\end{array}$} & \multicolumn{2}{|c|}{ Shares on the cash-only market } \\
\hline & & & & $\begin{array}{l}\text { Continuous } \\
\text { trading }\end{array}$ & Auction trading \\
\hline \multicolumn{2}{|l|}{ Total number of different stocks } & 352 & & & \\
\hline \multicolumn{2}{|l|}{ Breakdown of the number of stocks by market model } & 385 & 126 & 173 & 86 \\
\hline \multirow{4}{*}{$\begin{array}{l}\text { Repurchase intensity }=\text { Total euro value of shares } \\
\text { repurchased per firm over the sample period } \\
\text { expressed as a percentage of the initial market } \\
\text { capitalization. }\end{array}$} & Average & $1.78 \%$ & $2.29 \%$ & $1.55 \%$ & $1.50 \%$ \\
\hline & Median & $0.73 \%$ & $1.19 \%$ & $0.73 \%$ & $0.44 \%$ \\
\hline & Minimum & $0.000025 \%$ & $0.000025 \%$ & $0.0031 \%$ & $0.0017 \%$ \\
\hline & Maximum & $14.15 \%$ & $11.83 \%$ & $14.15 \%$ & $13.20 \%$ \\
\hline \multicolumn{2}{|c|}{ Total number of shares repurchased over the sample period (in million) } & 460.4 & 438.8 & 20.2 & 1.4 \\
\hline \multicolumn{2}{|c|}{ Average number of shares repurchased by a firm on one repurchase day } & 12,495 & 40,532 & 978 & 262 \\
\hline \multicolumn{2}{|c|}{ Total euro value of shares repurchased over the sample period (in million $€$ ) } & 33,925 & 33,285 & 525 & 115 \\
\hline \multicolumn{2}{|c|}{ Average euro value of shares repurchased by a firm on one repurchase day } & 920,678 & $3,074,585$ & 25,395 & 21,445 \\
\hline \multirow{2}{*}{$\begin{array}{l}\text { Size of share repurchase by a firm on one repurchase } \\
\text { day expressed as a percentage of the total trading } \\
\text { value volume of that day }\end{array}$} & Average & $27.90 \%$ & $14.22 \%$ & $27.54 \%$ & $56.6 \%$ \\
\hline & Median & $15.61 \%$ & $8.10 \%$ & $17.07 \%$ & $53 \%$ \\
\hline \multicolumn{2}{|l|}{ Total number of repurchase days } & 36,848 & 10,826 & 20,671 & 5,351 \\
\hline \multicolumn{2}{|l|}{ Average market capitalization per firm (in million $€$ ) } & $3,112.8$ & $9,351.9$ & $3,931.1$ & 76.9 \\
\hline \multicolumn{2}{|l|}{$\%$ of trading days including repurchase } & $20.21 \%$ & $18.13 \%$ & $23.40 \%$ & $15.60 \%$ \\
\hline \multicolumn{2}{|c|}{$\begin{array}{l}\text { Average number of share repurchase days per repurchase firm over the sample } \\
\text { period }\end{array}$} & 95.7 & 85.9 & 119.5 & 62.2 \\
\hline
\end{tabular}


Table 3

\section{Univariate tests of timing ability}

The sample consists of 352 stocks that were subject to at least one repurchase transaction over the period 2000-2002. Trading days with repurchases are separated from trading days with no repurchases. Panel A shows the results for the total sample. Panel B shows the results for the two subgroups: SRD (continuous trading with deferred trading facilities) and cash only-market. The value weighted average price is calculated as the average price of all transactions through the central order book, weighted according to the proportional value of the transaction on the trading day concerned. The variable "Vwap 2n months" is computed as the daily average of the Vwap n months before and $\mathrm{n}$ months after each trading day, excluding repurchase days. The "Vwap / Vwap 2n months" ratio is computed for each trading day. The "Vwap /Vwap n months before" and "Vwap /Vwap n months after" ratios are computed on the same model, respectively using the average price over the $\mathrm{n}$ months preceding the repurchase date, and the average price over the $\mathrm{n}$ months following the repurchase date. The market adjusted Vwap ratios are equal to the previous ratios divided by the same ratios over the same periods calculated using the SBF250 index. The last columns provide differences in means and in medians as well as parametric and non parametric tests to compare trading days with and without repurchases; * indicates statistical significance at the $1 \%$ level. The sum of the number of shares in the three subpanels is higher than 352 since some shares change market type during the period.

\begin{tabular}{|c|c|c|c|c|c|c|c|c|c|}
\hline \multicolumn{2}{|l|}{ Panel A } & \multicolumn{8}{|c|}{ All shares (352) } \\
\hline & & \multicolumn{4}{|c|}{ Vwap ratios } & \multicolumn{4}{|c|}{ Market adjusted vwap ratios } \\
\hline & & 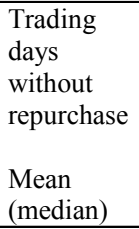 & \begin{tabular}{|l}
$\begin{array}{l}\text { Trading } \\
\text { days with } \\
\text { repurchase }\end{array}$ \\
Mean \\
(median) \\
\end{tabular} & $\begin{array}{l}\text { Difference } \\
\text { in means } \\
\text { (T- } \\
\text { statistic) }\end{array}$ & $\begin{array}{l}\text { Difference } \\
\text { in medians } \\
{[Z-} \\
\text { statistic] }\end{array}$ & $\begin{array}{l}\text { Trading } \\
\text { days } \\
\text { without } \\
\text { repurchase } \\
\text { Mean } \\
\text { (median) }\end{array}$ & $\begin{array}{l}\begin{array}{l}\text { Trading } \\
\text { days with } \\
\text { repurchase }\end{array} \\
\text { Mean } \\
\text { (median) } \\
\end{array}$ & $\begin{array}{l}\text { Difference } \\
\text { in means } \\
\text { (T-statistic) }\end{array}$ & $\begin{array}{l}\text { Difference } \\
\text { in medians } \\
{[\text { Z-statistic }]}\end{array}$ \\
\hline \multirow{3}{*}{$\begin{array}{l}\text { Vwap / Vwap } \\
2 \mathrm{n} \text { months (n } \\
\text { months } \\
\text { before and n } \\
\text { months after) }\end{array}$} & 1 month & $\begin{array}{l}0.99795 \\
(1.00000)\end{array}$ & $\begin{array}{l}0.98592 \\
(0.9914)\end{array}$ & $\begin{array}{l}0.012 \\
(29.73)^{*}\end{array}$ & $\begin{array}{l}0.0086 \\
{[-32.77]^{*}}\end{array}$ & $\begin{array}{l}0.99814 \\
(0.9979)\end{array}$ & $\begin{array}{l}0.99047 \\
(0.99139)\end{array}$ & $\begin{array}{l}0.0077 \\
(19.56)^{*}\end{array}$ & $\begin{array}{l}0.00651 \\
{[-19.37]^{*}}\end{array}$ \\
\hline & 2 months & $\begin{array}{l}0.99727 \\
(1.00029) \\
\end{array}$ & $\begin{array}{l}0.98280 \\
(0.98962) \\
\end{array}$ & $\begin{array}{l}0.0145 \\
(26.97)^{*}\end{array}$ & $\begin{array}{l}0.01067 \\
{[-30.33]^{*}} \\
\end{array}$ & $\begin{array}{l}0.99714 \\
(0.9960) \\
\end{array}$ & \begin{tabular}{|l|}
0.99030 \\
$(0.99032)$ \\
\end{tabular} & $\begin{array}{l}0.0068 \\
(13.33)^{*}\end{array}$ & $\begin{array}{l}0.00563 \\
{[-12.42]^{*}}\end{array}$ \\
\hline & 3 months & $\begin{array}{l}0.99600 \\
(0.99960) \\
\end{array}$ & $\begin{array}{l}0.97917 \\
(0.98639) \\
\end{array}$ & $\begin{array}{l}0.0168 \\
(26.96)^{*}\end{array}$ & $\begin{array}{l}0.01321 \\
{[-29.06]^{*}} \\
\end{array}$ & $\begin{array}{l}0.99625 \\
(0.9948) \\
\end{array}$ & \begin{tabular}{|l|}
0.98896 \\
$(0.98908)$ \\
\end{tabular} & $\begin{array}{l}0.0073 \\
(12.11)^{*}\end{array}$ & $\begin{array}{l}0.00575 \\
{[-10.58]^{*}} \\
\end{array}$ \\
\hline \multirow{3}{*}{$\begin{array}{l}\text { Vwap / Vwap } \\
\text { n months } \\
\text { before }\end{array}$} & 1 month & $\begin{array}{l}0.99662 \\
(0.99977) \\
\end{array}$ & $\begin{array}{l}0.97427 \\
(0.98400) \\
\end{array}$ & $\begin{array}{l}0.0223 \\
(41.71)^{*}\end{array}$ & \begin{tabular}{|l|}
0.01577 \\
{$[-46.30]^{*}$}
\end{tabular} & $\begin{array}{l}1.00423 \\
(1.0054)\end{array}$ & $\begin{array}{l}0.99013 \\
(0.99375) \\
\end{array}$ & $\begin{array}{l}0.0141 \\
(27.20)^{*}\end{array}$ & $\begin{array}{l}0.01167 \\
{[-26.89]^{*}}\end{array}$ \\
\hline & 2 months & $\begin{array}{l}0.99169 \\
(0.99898) \\
\end{array}$ & $\begin{array}{l}0.96448 \\
(0.97824) \\
\end{array}$ & $\begin{array}{l}0.0272 \\
(40.13)^{*}\end{array}$ & $\begin{array}{l}0.02074 \\
{[-44.99]^{*}}\end{array}$ & $\begin{array}{l}1.00640 \\
(1.0097)\end{array}$ & $\begin{array}{l}0.99199 \\
(0.99766) \\
\end{array}$ & $\begin{array}{l}0.0144 \\
(21.79)^{*}\end{array}$ & $\begin{array}{l}0.01206 \\
{[-20.14]^{*}}\end{array}$ \\
\hline & 3 months & $\begin{array}{l}0.98501 \\
(0.99649) \\
\end{array}$ & $\begin{array}{l}0.95669 \\
(0.97259) \\
\end{array}$ & $\begin{array}{l}0.0283 \\
(36.18)^{*}\end{array}$ & \begin{tabular}{|l|}
0.0239 \\
{$[-41.60]^{*}$} \\
\end{tabular} & $\begin{array}{l}1.00836 \\
(1.0142) \\
\end{array}$ & \begin{tabular}{|l|}
0.99508 \\
$(1.00275)$ \\
\end{tabular} & $\begin{array}{l}0.0133 \\
(17.24)^{*}\end{array}$ & $\begin{array}{l}0.01149 \\
{[-16.26]^{*}}\end{array}$ \\
\hline \multirow{3}{*}{$\begin{array}{l}\text { Vwap / Vwap } \\
\text { n months } \\
\text { after }\end{array}$} & 1 month & $\begin{array}{l}1.00742 \\
(1.00090) \\
\end{array}$ & $\begin{array}{l}1.00653 \\
(0.99869) \\
\end{array}$ & $\begin{array}{l}0.0009 \\
(1.56) \\
\end{array}$ & $\begin{array}{l}0.00221 \\
{[-7.79]^{*}} \\
\end{array}$ & $\begin{array}{l}0.99862 \\
(0.9933) \\
\end{array}$ & $\begin{array}{l}0.99859 \\
(0.99137) \\
\end{array}$ & $\begin{array}{l}0.00003 \\
(0.060) \\
\end{array}$ & $\begin{array}{l}0.00196 \\
{[-4.68]^{*}}\end{array}$ \\
\hline & 2 months & $\begin{array}{l}1.01634 \\
(1.00194) \\
\end{array}$ & $\begin{array}{l}1.01490 \\
(0.99959) \\
\end{array}$ & $\begin{array}{l}0.0014 \\
(1.86) \\
\end{array}$ & $\begin{array}{l}0.00235 \\
{[-5.50]^{*}} \\
\end{array}$ & $\begin{array}{l}0.99850 \\
(0.9864) \\
\end{array}$ & \begin{tabular}{|l|}
0.99927 \\
$(0.98538)$ \\
\end{tabular} & $\begin{array}{l}-0.00077 \\
(-1.09) \\
\end{array}$ & $\begin{array}{l}0.00104 \\
{[-1.78]} \\
\end{array}$ \\
\hline & 3 months & $\begin{array}{l}1.02568 \\
(1.00352) \\
\end{array}$ & $\begin{array}{l}1.02241 \\
(1.00025) \\
\end{array}$ & $\begin{array}{l}0.0033 \\
(3.50)^{*}\end{array}$ & $\begin{array}{l}0.00327 \\
{[-5.89]^{*}}\end{array}$ & $\begin{array}{l}0.99834 \\
(0.9798) \\
\end{array}$ & \begin{tabular}{|l|}
0.99797 \\
$(0.97844)$
\end{tabular} & $\begin{array}{l}0.0004 \\
(0.44) \\
\end{array}$ & $\begin{array}{l}0.00138 \\
{[-2.19]}\end{array}$ \\
\hline
\end{tabular}




\begin{tabular}{|c|c|c|c|c|c|c|c|c|c|}
\hline \multicolumn{2}{|l|}{ Panel B } & \multicolumn{8}{|c|}{ Subsamples } \\
\hline & & \multicolumn{8}{|c|}{ SRD shares (129) } \\
\hline & & \multicolumn{4}{|c|}{ Vwap ratios } & \multicolumn{4}{|c|}{ Market adjusted vwap ratios } \\
\hline & & $\begin{array}{l}\text { Trading } \\
\text { days } \\
\text { without } \\
\text { repurchase } \\
\text { Mean } \\
\text { (median) }\end{array}$ & 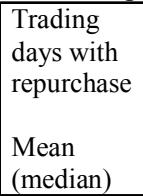 & $\begin{array}{l}\text { Difference } \\
\text { in means } \\
(\mathrm{T}- \\
\text { statistic) }\end{array}$ & $\begin{array}{l}\text { Difference } \\
\text { in medians } \\
{[Z-} \\
\text { statistic] }\end{array}$ & \begin{tabular}{|l|} 
Trading \\
days \\
without \\
repurchase \\
Mean \\
(median)
\end{tabular} & 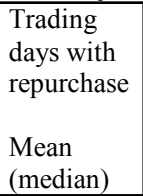 & $\begin{array}{l}\text { Difference } \\
\text { in means } \\
\text { (T-statistic) }\end{array}$ & \begin{tabular}{|l} 
Difference \\
in medians \\
[Z-statistic]
\end{tabular} \\
\hline \multirow{3}{*}{$\begin{array}{l}\text { Vwap / Vwap } \\
2 \mathrm{n} \text { months (n } \\
\text { months } \\
\text { before and n } \\
\text { months after) }\end{array}$} & 1 month & $\begin{array}{l}0.99823 \\
(1.00032)\end{array}$ & $\begin{array}{l}0.98465 \\
(0.98818)\end{array}$ & $\begin{array}{l}0.0136 \\
(19.67)^{*}\end{array}$ & $\begin{array}{l}0.01214 \\
{[-24.55]^{*}}\end{array}$ & $\begin{array}{l}0.99786 \\
(0.9979)\end{array}$ & $\begin{array}{l}0.99066 \\
(0.99032)\end{array}$ & $\begin{array}{l}0.0072 \\
(11.50)^{*}\end{array}$ & $\begin{array}{l}0.00763 \\
{[-13.81]^{*}}\end{array}$ \\
\hline & 2 months & $\begin{array}{l}0.99823 \\
(1.00188)\end{array}$ & $\begin{array}{l}0.98065 \\
(0.98685)\end{array}$ & $\begin{array}{l}0.0176 \\
(20.47)^{*}\end{array}$ & $\begin{array}{l}0.01503 \\
{[-23.60]^{*}}\end{array}$ & $\begin{array}{l}0.99736 \\
(0.9962)\end{array}$ & $\begin{array}{l}0.99014 \\
(0.98829) \\
\end{array}$ & \begin{tabular}{|l|}
0.0072 \\
$(9.32)^{*}$ \\
\end{tabular} & \begin{tabular}{|l|}
0.00786 \\
{$[-10.65]^{*}$} \\
\end{tabular} \\
\hline & 3 months & $\begin{array}{l}0.99717 \\
(1.00138)\end{array}$ & $\begin{array}{l}0.97589 \\
(0.98348)\end{array}$ & $\begin{array}{l}0.0213 \\
(22.64)^{*}\end{array}$ & $\begin{array}{l}0.0179 \\
{[-22.42]^{*}}\end{array}$ & $\begin{array}{l}0.99651 \\
(0.9951)\end{array}$ & $\begin{array}{l}0.98771 \\
(0.98625)\end{array}$ & $\begin{array}{l}0.0088 \\
(10.22)^{*}\end{array}$ & $\begin{array}{l}0.00885 \\
{[-10.42]^{*}}\end{array}$ \\
\hline \multirow{3}{*}{$\begin{array}{l}\text { Vwap / Vwap } \\
\text { n months } \\
\text { before }\end{array}$} & 1 month & $\begin{array}{l}0.99654 \\
(1.00033)\end{array}$ & $\begin{array}{l}0.97148 \\
(0.97979)\end{array}$ & $\begin{array}{l}0.0251 \\
(27.63)^{*}\end{array}$ & $\begin{array}{l}0.02054 \\
{[-31.56]^{*}}\end{array}$ & $\begin{array}{l}1.00255 \\
(1.0046)\end{array}$ & $\begin{array}{l}0.98796 \\
(0.99064)\end{array}$ & \begin{tabular}{|l|l}
0.0146 \\
$(17.76)^{*}$
\end{tabular} & $\begin{array}{l}0.01395 \\
{[-19.14]^{*}}\end{array}$ \\
\hline & 2 months & $\begin{array}{l}0.99176 \\
(1.00000)\end{array}$ & $\begin{array}{l}0.96127 \\
(0.97195) \\
\end{array}$ & \begin{tabular}{|l|}
0.0305 \\
$(28.31)^{*}$
\end{tabular} & $\begin{array}{l}0.02805 \\
{[-31.83]^{*}}\end{array}$ & $\begin{array}{l}1.00366 \\
(1.0083) \\
\end{array}$ & $\begin{array}{l}0.98794 \\
(0.99234)\end{array}$ & $\begin{array}{l}0.0157 \\
(15.65)^{*}\end{array}$ & $\begin{array}{l}0.016 \\
{[-14.75]^{*}}\end{array}$ \\
\hline & 3 months & $\begin{array}{l}0.98488 \\
(0.99678)\end{array}$ & \begin{tabular}{|l|}
0.95368 \\
$(0.96406)$ \\
\end{tabular} & \begin{tabular}{|l|}
0.0312 \\
$(25.32)^{*}$
\end{tabular} & $\begin{array}{l}0.03272 \\
{[-29.68]^{*}}\end{array}$ & \begin{tabular}{|l|}
1.00440 \\
$(1.0111)$ \\
\end{tabular} & $\begin{array}{l}0.98924 \\
(0.99444) \\
\end{array}$ & \begin{tabular}{|l|}
0.0152 \\
$(13.34)^{*}$ \\
\end{tabular} & \begin{tabular}{|l|}
0.01661 \\
{$[-13.84]^{*}$}
\end{tabular} \\
\hline \multirow{3}{*}{$\begin{array}{l}\text { Vwap / Vwap } \\
\text { n months } \\
\text { after }\end{array}$} & 1 month & $\begin{array}{l}1.00671 \\
(1.00041) \\
\end{array}$ & $\begin{array}{l}1.00431 \\
(0.99486) \\
\end{array}$ & $\begin{array}{l}0.0024 \\
(2.46)^{*} \\
\end{array}$ & $\begin{array}{l}0.00555 \\
{[-10.38]^{*}}\end{array}$ & $\begin{array}{l}0.99827 \\
(0.9938) \\
\end{array}$ & $\begin{array}{l}0.99905 \\
(0.99082)\end{array}$ & \begin{tabular}{|l|}
-0.00078 \\
$(-0.95)$ \\
\end{tabular} & $\begin{array}{l}0.00296 \\
{[-4.24] *} \\
\end{array}$ \\
\hline & 2 months & $\begin{array}{l}1.01426 \\
(1.00156)\end{array}$ & $\begin{array}{l}1.01004 \\
(0.99486)\end{array}$ & $\begin{array}{l}0.0042 \\
(3.47)^{*}\end{array}$ & $\begin{array}{l}0.0067 \\
{[-8.14]^{*}}\end{array}$ & $\begin{array}{c}0.99726 \\
(0.9876)\end{array}$ & $\begin{array}{l}0.99858 \\
(0.98574) \\
\end{array}$ & \begin{tabular}{|l|}
-0.001 \\
$(-1.28)$ \\
\end{tabular} & \begin{tabular}{|l|}
0.00184 \\
{$[-1.96]$} \\
\end{tabular} \\
\hline & 3 months & $\begin{array}{l}1.02179 \\
(1.00373)\end{array}$ & $\begin{array}{l}1.01334 \\
(0.99525)\end{array}$ & $\begin{array}{l}0.0085 \\
(5.98)^{*}\end{array}$ & $\begin{array}{l}0.00848 \\
{[-8.19]^{*}}\end{array}$ & $\begin{array}{l}0.99569 \\
(0.9810)\end{array}$ & $\begin{array}{l}0.99488 \\
(0.97868)\end{array}$ & \begin{tabular}{|l|}
0.0008 \\
$(0.68)$
\end{tabular} & \begin{tabular}{|l|}
0.00229 \\
{$[-2.25]$}
\end{tabular} \\
\hline & & \multicolumn{8}{|c|}{ Cash only market (256 shares) } \\
\hline & & \multicolumn{4}{|c|}{ Vwap ratios } & \multicolumn{4}{|c|}{ Market adjusted vwap ratios } \\
\hline & & $\begin{array}{l}\text { Trading } \\
\text { days } \\
\text { without } \\
\text { repurchase } \\
\text { Mean } \\
\text { (median) }\end{array}$ & 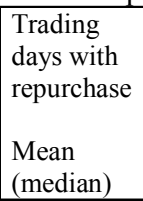 & $\begin{array}{l}\text { Difference } \\
\text { in means } \\
\text { (T- } \\
\text { statistic) }\end{array}$ & $\begin{array}{l}\text { Difference } \\
\text { in medians } \\
{[Z-} \\
\text { statistic }]\end{array}$ & \begin{tabular}{|l|} 
Trading \\
days \\
without \\
repurchase \\
Mean \\
(median) \\
\end{tabular} & $\begin{array}{l}\begin{array}{l}\text { Trading } \\
\text { days with } \\
\text { repurchase }\end{array} \\
\begin{array}{l}\text { Mean } \\
\text { (median) }\end{array}\end{array}$ & \begin{tabular}{|l|} 
Difference \\
in means \\
(T-statistic)
\end{tabular} & \begin{tabular}{|l} 
Difference \\
in medians \\
[Z-statistic]
\end{tabular} \\
\hline \multirow{3}{*}{$\begin{array}{l}\text { Vwap / Vwap } \\
2 \mathrm{n} \text { months (n } \\
\text { months } \\
\text { before and } \mathrm{n} \\
\text { months after) }\end{array}$} & 1 month & $\begin{array}{l}0.99782 \\
(0.99990)\end{array}$ & \begin{tabular}{|l|}
0.98645 \\
$(0.99278)$ \\
\end{tabular} & $\begin{array}{l}0.0114 \\
(22.82)^{*}\end{array}$ & $\begin{array}{l}0.00712 \\
{[-23.11]^{*}}\end{array}$ & $\begin{array}{l}0.99828 \\
(0.99786) \\
\end{array}$ & $\begin{array}{l}0.99038 \\
(0.99188)\end{array}$ & $\begin{array}{l}0.0079 \\
(16.01)^{*}\end{array}$ & \begin{tabular}{|l|}
0.00598 \\
{$[-14.09]^{*}$}
\end{tabular} \\
\hline & 2 months & $\begin{array}{l}0.99679 \\
(0.99980)\end{array}$ & $\begin{array}{l}0.98369 \\
(0.99086)\end{array}$ & $\begin{array}{l}0.0131 \\
(19.43)^{*}\end{array}$ & $\begin{array}{l}0.0012 \\
{[-20.72]^{*}}\end{array}$ & $\begin{array}{l}0.99703 \\
(0.99582)\end{array}$ & $\begin{array}{l}0.99037 \\
(0.99137)\end{array}$ & $\begin{array}{l}0.0067 \\
(10.17)^{*}\end{array}$ & $\begin{array}{l}0.00445 \\
{[-7.88]^{*}}\end{array}$ \\
\hline & 3 months & $\begin{array}{l}0.99540 \\
(0.99876) \\
\end{array}$ & \begin{tabular}{|l|}
0.98053 \\
$(0.98762)$ \\
\end{tabular} & \begin{tabular}{|l|}
0.0149 \\
$(18.67)^{*}$
\end{tabular} & $\begin{array}{l}0.01114 \\
{[-19.75]^{*}}\end{array}$ & $\begin{array}{l}0.99611 \\
(0.99464) \\
\end{array}$ & $\begin{array}{l}0.98948 \\
(0.99062) \\
\end{array}$ & \begin{tabular}{|l|}
0.0066 \\
$(8.53)^{*}$ \\
\end{tabular} & $\begin{array}{l}0.00402 \\
{[-5.869]^{*}} \\
\end{array}$ \\
\hline \multirow{3}{*}{$\begin{array}{l}\text { Vwap / Vwap } \\
\text { n months } \\
\text { before }\end{array}$} & 1 month & $\begin{array}{l}0.99666 \\
(0.99955)\end{array}$ & $\begin{array}{l}0.97539 \\
(0.98568)\end{array}$ & $\begin{array}{l}0.0213 \\
(32.23)^{*}\end{array}$ & $\begin{array}{l}0.01387 \\
{[-34.83]^{*}}\end{array}$ & $\begin{array}{l}1.00508 \\
(1.00592)\end{array}$ & $\begin{array}{l}0.99100 \\
(0.99515)\end{array}$ & $\begin{array}{l}0.0141 \\
(21.62)^{*}\end{array}$ & $\begin{array}{l}0.01077 \\
{[-19.64]^{*}}\end{array}$ \\
\hline & 2 months & $\begin{array}{l}0.99165 \\
(0.99860) \\
\end{array}$ & \begin{tabular}{|l|}
0.96582 \\
$(0.98071)$ \\
\end{tabular} & \begin{tabular}{|l|}
0.0258 \\
$(30.11)^{*}$ \\
\end{tabular} & $\begin{array}{l}0.01789 \\
{[-32.92]^{*}}\end{array}$ & $\begin{array}{l}1.00778 \\
(1.01047) \\
\end{array}$ & $\begin{array}{l}0.99368 \\
(1.00024) \\
\end{array}$ & \begin{tabular}{|l|}
0.0141 \\
$(16.74)^{*}$
\end{tabular} & $\begin{array}{l}0.01023 \\
{[-14.10]^{*}} \\
\end{array}$ \\
\hline & 3 months & $\begin{array}{l}0.98507 \\
(0.99630)\end{array}$ & \begin{tabular}{|l|}
0.95795 \\
$(0.97605)$ \\
\end{tabular} & \begin{tabular}{|l|}
0.0271 \\
$(27.61)^{*}$
\end{tabular} & $\begin{array}{l}0.02025 \\
{[-30.64]^{*}}\end{array}$ & $\begin{array}{l}1.01037 \\
(1.01603)\end{array}$ & $\begin{array}{l}0.99751 \\
(1.00662)\end{array}$ & $\begin{array}{l}0.0129 \\
(13.01)^{*}\end{array}$ & $\begin{array}{l}0.00941 \\
{[-10.99]^{*}}\end{array}$ \\
\hline \multirow{3}{*}{$\begin{array}{l}\text { Vwap / Vwap } \\
\text { n months } \\
\text { after }\end{array}$} & 1 month & $\begin{array}{l}1.00778 \\
(1.00112)\end{array}$ & \begin{tabular}{|l|}
1.00742 \\
$(1.00000)$ \\
\end{tabular} & $\begin{array}{l}0.0004 \\
(0.52)\end{array}$ & $\begin{array}{l}0.00112 \\
{[-3.41]^{*}}\end{array}$ & $\begin{array}{l}0.99880 \\
(0.99308) \\
\end{array}$ & $\begin{array}{l}0.99840 \\
(0.99153)\end{array}$ & \begin{tabular}{|l}
0.0004 \\
$(0.60)$
\end{tabular} & \begin{tabular}{|l|}
0.00155 \\
{$[-2.82]^{*}$}
\end{tabular} \\
\hline & 2 months & $\begin{array}{l}1.01739 \\
(1.00211)\end{array}$ & \begin{tabular}{|l|}
1.01694 \\
$(1.00141)$ \\
\end{tabular} & $\begin{array}{l}0.0005 \\
(0.46)\end{array}$ & $\begin{array}{l}0.0007 \\
{[-1.12]}\end{array}$ & $\begin{array}{l}0.99912 \\
(0.98575) \\
\end{array}$ & $\begin{array}{l}0.99955 \\
(0.98528) \\
\end{array}$ & \begin{tabular}{|l|}
-0.00043 \\
$(-0.47)$ \\
\end{tabular} & \begin{tabular}{|l|}
0.00047 \\
{$[-0.71]$} \\
\end{tabular} \\
\hline & 3 months & $\begin{array}{l}1.02765 \\
(1.00341)\end{array}$ & $\begin{array}{l}1.02621 \\
(1.00231)\end{array}$ & $\begin{array}{l}0.0014 \\
(0.21)\end{array}$ & $\begin{array}{l}0.0011 \\
{[-1.56]}\end{array}$ & $\begin{array}{l}0.99968 \\
(0.97919)\end{array}$ & $\begin{array}{l}0.99926 \\
(0.97832)\end{array}$ & $\begin{array}{l}0.0004 \\
(0.38)\end{array}$ & $\begin{array}{l}0.00087 \\
{[-1.15]}\end{array}$ \\
\hline
\end{tabular}


Table 4

\section{Rates of return around the repurchase trading days}

Rates of return are measured, based on midpoints, for the 352 stocks that were subject to at least one repurchase transaction over the period 2000-2002. The rate of return for a given trading day is calculated from that day's opening to the next day's opening $(\mathrm{O}-\mathrm{O})$. A more detailed analysis is used for the repurchase day and the preceding day. The preceding day's rate of return is broken down into two components, one being the rate observed from the first to the last transaction price (O-C), and the other the rate observed off hours, from the last transaction price to the first transaction price of the repurchase day (C-O). Four rates of return are examined for the repurchase day. The first $(\mathrm{O}-\mathrm{C})$ covers the period from open to close of trade, and is provided for easier comparison of total trading hours on repurchase and non-repurchase days. The second measures developments in price from the opening to repurchase (O-R), the third runs from the repurchase to the close of trade (R-C), and the fourth from the close to the next day's opening (C-O). These results are compared with the rates of return noted when no repurchase takes place. On non-repurchase days, the rate of return breakdown is limited to the rate for trading hours $(\mathrm{O}-\mathrm{C})$, and the off hours rate $(\mathrm{C}-\mathrm{O})$. T-statistics and Z-statistics are provided to compare rates of return during trading days with and without repurchase. * indicates statistical significance at the $1 \%$ level.

\begin{tabular}{|c|c|c|c|c|c|c|c|c|c|c|c|c|}
\hline & \multirow{2}{*}{$\begin{array}{c}\text { R-2 } \\
\text { O-O } \\
\text { Mean } \\
\text { (Median) } \\
\end{array}$} & \multicolumn{2}{|c|}{$\mathrm{R}-1$} & \multicolumn{4}{|c|}{ Repurchase Day } & \multirow{2}{*}{$\begin{array}{c}\mathrm{R}+1 \\
\mathrm{O}-\mathrm{O} \\
\text { Mean } \\
\text { (Median) }\end{array}$} & \multirow{2}{*}{$\begin{array}{c}\mathrm{R}+2 \\
\mathrm{O}-\mathrm{O} \\
\text { Mean } \\
\text { (Median) }\end{array}$} & \multirow{2}{*}{$\begin{array}{c}\mathrm{R}+3 \\
\mathrm{O}-\mathrm{O} \\
\text { Mean } \\
\text { (Median) }\end{array}$} & \multirow{2}{*}{$\begin{array}{c}\mathrm{R}+4 \\
\mathrm{O}-\mathrm{O} \\
\text { Mean } \\
\text { (Median) }\end{array}$} & \multirow{2}{*}{$\begin{array}{c}\mathrm{R}+5 \\
\mathrm{O}-\mathrm{O} \\
\text { Mean } \\
\text { (Median) }\end{array}$} \\
\hline & & $\begin{array}{c}\text { O-C } \\
\text { Mean } \\
\text { (Median) }\end{array}$ & $\begin{array}{c}\text { C-O } \\
\text { Mean } \\
\text { (Median) }\end{array}$ & $\begin{array}{c}\text { O-C } \\
\text { Mean } \\
\text { (Median) }\end{array}$ & $\begin{array}{c}\text { O-R } \\
\text { Mean } \\
\text { (Median) }\end{array}$ & $\begin{array}{c}\text { R-C } \\
\text { Mean } \\
\text { (Median) }\end{array}$ & $\begin{array}{c}\mathrm{C}-\mathrm{O} \\
\text { Mean } \\
\text { (Median) }\end{array}$ & & & & & \\
\hline No repurchase, all stocks & $\begin{array}{r}0.016 \% \\
(0.000)\end{array}$ & $\begin{array}{r}-0.053 \% \\
(0.000)\end{array}$ & $\begin{array}{r}0.121 \% \\
(0.000)\end{array}$ & $\begin{array}{r}-0.022 \% \\
(0.000)\end{array}$ & & & $\begin{array}{r}0.088 \% \\
(0.000)\end{array}$ & $\begin{array}{r}-0.023 \% \\
(0.000)\end{array}$ & $\begin{array}{r}-0.023 \% \\
(0.000)\end{array}$ & $\begin{array}{r}-0.021 \% \\
(0.000)\end{array}$ & $\begin{array}{r}-0.024 \% \\
(0.000)\end{array}$ & $\begin{array}{r}-0.020 \% \\
(0.000)\end{array}$ \\
\hline Repurchase, all stocks & $\begin{array}{r}-0.167 \% \\
(-0.052 \%) \\
\end{array}$ & $\begin{array}{r}-0.174 \% \\
(0.000) \\
\end{array}$ & $\begin{array}{r}-0.132 \% \\
(-0.0032 \%) \\
\end{array}$ & $\begin{array}{r}-0.287 \% \\
(0.000)\end{array}$ & $\begin{array}{r}-0.331 \% \\
(-0.306 \%)\end{array}$ & $\begin{array}{r}0.076 \% \\
(0.033 \%) \\
\end{array}$ & $\begin{array}{r}-0.027 \% \\
(0.000)\end{array}$ & $\begin{array}{r}-0.016 \% \\
(0.000) \\
\end{array}$ & $\begin{array}{r}-0.001 \% \\
(0.000)\end{array}$ & $\begin{array}{r}-0.015 \% \\
(0.000)\end{array}$ & $\begin{array}{r}-0.005 \% \\
(0.000)\end{array}$ & $\begin{array}{r}-0.032 \% \\
(0.000)\end{array}$ \\
\hline No repurchase, SRD stocks & $\begin{array}{r}0.002 \% \\
(-0.037 \%)\end{array}$ & $\begin{array}{r}-0.062 \% \\
(-0.048 \%)\end{array}$ & $\begin{array}{r}0.110 \% \\
(0.043 \%)\end{array}$ & $\begin{array}{r}-0.026 \% \\
(-0.030 \%)\end{array}$ & & & $\begin{array}{r}0.086 \% \\
(0.033 \%)\end{array}$ & $\begin{array}{r}-0.038 \% \\
(-0.057 \%)\end{array}$ & $\begin{array}{r}-0.031 \% \\
(-0.054 \%)\end{array}$ & $\begin{array}{r}-0.021 \% \\
(-0.050 \%)\end{array}$ & $\begin{array}{r}-0.021 \% \\
(-0.049 \%)\end{array}$ & $\begin{array}{r}-0.023 \% \\
(-0.053 \%)\end{array}$ \\
\hline Repurchase, SRD stocks & $\begin{array}{r}-0.154 \% \\
(-0.125 \%) \\
\end{array}$ & $\begin{array}{r}-0.218 \% \\
(-0.126 \%)\end{array}$ & $\begin{array}{r}-0.126 \% \\
(-0.072 \%) \\
\end{array}$ & $\begin{array}{r}-0.373 \% \\
(-0.234 \%) \\
\end{array}$ & $\begin{array}{r}-0.606 \% \\
(-0.414 \%) \\
\end{array}$ & $\begin{array}{r}0.237 \% \\
(0.106 \%) \\
\end{array}$ & $\begin{array}{r}-0.024 \% \\
(-0.029 \%)\end{array}$ & $\begin{array}{l}0.036 \% \\
(0.000)\end{array}$ & $\begin{array}{l}0.032 \% \\
(0.000)\end{array}$ & $\begin{array}{r}-0.008 \% \\
(-0.032 \%)\end{array}$ & $\begin{array}{r}-0.010 \% \\
(-0.039 \%)\end{array}$ & $\begin{array}{r}-0.019 \% \\
(-0.035 \%)\end{array}$ \\
\hline No repurchase, Cash stocks & $\begin{array}{r}0.024 \% \\
(0.000) \\
\end{array}$ & $\begin{array}{r}-0.049 \% \\
(0.000) \\
\end{array}$ & $\begin{array}{l}0.128 \% \\
(0.000)\end{array}$ & $\begin{array}{r}-0.020 \% \\
(0.000) \\
\end{array}$ & & & $\begin{array}{r}0.089 \% \\
(0.000)\end{array}$ & $\begin{array}{r}-0.015 \% \\
(0.000) \\
\end{array}$ & $\begin{array}{r}-0.018 \% \\
(0.000) \\
\end{array}$ & $\begin{array}{r}-0.021 \% \\
(0.000)\end{array}$ & $\begin{array}{r}-0.026 \% \\
(0.000)\end{array}$ & $\begin{array}{r}-0.018 \% \\
(0.000)\end{array}$ \\
\hline Repurchase, Cash stocks & $\begin{array}{r}-0.173 \% \\
(-0.032 \%)\end{array}$ & $\begin{array}{r}-0.155 \% \\
(0.000)\end{array}$ & $\begin{array}{r}-0.134 \% \\
(0.000)\end{array}$ & $\begin{array}{r}-0.250 \% \\
(0.000)\end{array}$ & $\begin{array}{r}-0.216 \% \\
(-0.247 \%)\end{array}$ & $\begin{array}{l}0.007 \% \\
(0.000)\end{array}$ & $\begin{array}{r}-0.028 \% \\
(0.000)\end{array}$ & $\begin{array}{r}-0.039 \% \\
(0.000)\end{array}$ & $\begin{array}{r}-0.016 \% \\
(0.000)\end{array}$ & $\begin{array}{r}-0.018 \% \\
(0.000)\end{array}$ & $\begin{array}{r}-0.003 \% \\
(0.000)\end{array}$ & $\begin{array}{r}-0.038 \% \\
(0.000)\end{array}$ \\
\hline & -9.74 & $-7.72 *$ & $-19.73^{*}$ & -16.7 & & & & 0. & 1. & 0. & 1.00 & -0.65 \\
\hline Z-sta & $11.89^{*}$ & $6.67 *$ & $22.62 *$ & $16.96^{*}$ & & & $10.2-3$ & 0.01 & -0.15 & -0.48 & -0.39 & 0.14 \\
\hline T-statistics (SRD stocks) & $-5.23 *$ & $-5.98 *$ & $-14.25 *$ & $-13.05 *$ & & & $-6.67 *$ & 2.45 & 2.11 & 0.44 & 0.35 & 0.15 \\
\hline Z-statistics (SRD stocks) & $5.17 *$ & $4.65^{*}$ & $14.27 *$ & $11.59^{*}$ & & & $7.89^{*}$ & $-2.62 *$ & $-2.70^{*}$ & -1.55 & -1.06 & -1.43 \\
\hline T-statistics (Cash stocks) & $-8.26 *$ & $-5.47 *$ & $-15.32 *$ & $-11.72 *$ & & & $-7.02 *$ & -1.00 & 0.11 & 0.11 & 0.96 & -0.84 \\
\hline Z-statistics (Cash stocks) & $10.63 *$ & $5.28^{*}$ & $17.58^{*}$ & $12.84 *$ & & & $7.01 *$ & 1.78 & 1.44 & 0.26 & 0.13 & 0.92 \\
\hline
\end{tabular}




\section{Table 5}

\section{Detailed analysis of bid-ask spread liquidity effects}

The sample consists of 352 stocks that were subject to at least one repurchase transaction over the period 20002002. The average (median) effective relative spread (first column) is computed over all trading days when a repurchase transaction was reported to the AMF (regardless of transaction volume). The calculation uses either the first spread after the call auction, or the average of all spreads available for the trading day, which are compared with the spreads for the dates surrounding the repurchase days. The pre-repurchase period covers the 20 trading days before the buyback, excluding repurchase days. The trading day before the repurchase day is called the lag day, and the day after repurchase the lead day. Only lag and lead days without repurchases are used in these calculations. T-statistics and Z-statistics are provided to compare spreads during trading days with and without repurchase. ${ }^{*}(*)$ indicates statistical significance at the $1 \%(5 \%)$ level.

\begin{tabular}{|c|c|c|c|c|c|}
\hline & & \multirow{2}{*}{$\begin{array}{l}\text { Effective } \\
\text { relative } \\
\text { repurchase } \\
\text { day spread }\end{array}$} & \multicolumn{3}{|c|}{$\begin{array}{l}\text { Relative effective spread around } \\
\text { repurchase days }\end{array}$} \\
\hline & & & $\begin{array}{c}\text { Pre- } \\
\text { repurchase } \\
\text { period }\end{array}$ & Lag day & Lead Day \\
\hline \multicolumn{6}{|l|}{ Full sample } \\
\hline \multirow[t]{2}{*}{ Spread-first } & Mean (T-statistic) & $2.40 \%$ & $2.26 \%(6.03 *)$ & $2.33 \%(2.02 * *)$ & $2.42 \%(-0.67)$ \\
\hline & Median (Z-statistic) & $1.46 \%$ & $1.50 \%(1.82)$ & $1.42 \%(-1.66)$ & $1.53\left(2.49^{* *}\right)$ \\
\hline \multirow[t]{2}{*}{ Spread-average } & Mean (T-statistic) & $2.08 \%$ & $1.97 \%(3.75 *)$ & $2.02 \%(1.30)$ & $2.09 \%(-0.13)$ \\
\hline & Median (Z-statistic) & $1.35 \%$ & $1.30 \%(-2.46 * *)$ & $1.30 \%\left(-2.25^{* *}\right)$ & $1.35 \%(-0.10)$ \\
\hline \multicolumn{6}{|l|}{ SRD shares } \\
\hline \multirow[t]{2}{*}{ Spread-first } & Mean (T-statistic) & $0.90 \%$ & $0.85 \%(3.34 *)$ & $0.85 \%(2.41 * *)$ & $0.90 \%(0.67)$ \\
\hline & Median (Z-statistic) & $0.56 \%$ & $0.68 \%(7.64 *)$ & $0.54 \%(-1.60)$ & $0.56 \%(-0.21)$ \\
\hline \multirow[t]{2}{*}{ Spread-average } & Mean (T-statistic) & $0.55 \%$ & $0.53 \%\left(1.88^{* *}\right)$ & $0.51 \%\left(2.85^{*}\right)$ & $0.53 \%(1.05)$ \\
\hline & Median (Z-statistic) & $0.41 \%$ & $0.38 \%(-2.70 *)$ & $0.37 \%(-3.19 *)$ & $0.39 \%(-1.34)$ \\
\hline \multicolumn{6}{|l|}{ Cash only market } \\
\hline \multirow[t]{2}{*}{ Spread-first } & Mean (T-statistic) & $3.05 \%$ & $2.84 \%(6.57 *)$ & $2.83 \%\left(4.97^{*}\right)$ & $2.94 \%(2.49 * *)$ \\
\hline & Median (Z-statistic) & $2.06 \%$ & $1.93 \%\left(-5.81^{*}\right)$ & $1.90 \%\left(-5.86^{*}\right)$ & $2.00 \%\left(-2.57^{*}\right)$ \\
\hline \multirow[t]{2}{*}{ Spread-average } & Mean (T-statistic) & $2.73 \%$ & $2.55 \%\left(4.55^{*}\right)$ & $2.53 \%(3.53 *)$ & $2.60 \%\left(2.15^{* *}\right)$ \\
\hline & Median (Z-statistic) & $1.96 \%$ & $1.74 \%\left(-11.96^{*}\right)$ & $1.80 \%(-7.72 *)$ & $1.84 \%(-5.50 *)$ \\
\hline
\end{tabular}


Table 6

Determinants of liquidity and the repurchase decision

This table reports regressions that relate liquidity to several factors for the sample of the 352 stocks that were subject to at least one repurchase transaction over the period 2000-2002, using the following regression model.

$$
\text { LIQUIDITY }_{\mathrm{i}}=\alpha+\beta 0 \mathrm{REPURCH}_{\mathrm{i}}+\gamma 1 \mathrm{VOLAT}+\gamma 2 \operatorname{VOLUME}_{\mathrm{i}}+\gamma 3 \mathrm{SRD}_{\mathrm{i}}+\gamma 4 \mathrm{MM}_{\mathrm{i}}+\varepsilon_{\mathrm{i}}
$$

Liquidity is represented by either effective relative spread or depth for the firm-trading day i. Depth is measured using the data closest to the opening of the trading day. The effective relative bid-ask spread is calculated as follows:

$$
\text { Effective RelativeSpread }=\frac{2 \times \mid \text { Trade Price }- \text { Midpoint } \mid}{\text { Midpoint }} \text { where Midpoint }=\frac{\text { Ask Price }+ \text { Bid Price }}{2}
$$

The calculation uses either the first after the call auction or the average of all spreads available for the trading day. REPURCH is a dummy variable that takes the value of one if the firm has repurchased shares on the given trading day, and zero otherwise. VOLAT is the annualized estimate of daily volatility over the preceding 21 days. VOLUME is the log of the daily turnover in euros. SRD is a dummy variable that takes the value of one if the share is eligible for trading with deferred settlement facilities that day, and zero otherwise. MM is a dummy variable that takes the value of one if the share is subject to auction trading, and zero otherwise. Coefficients and

\begin{tabular}{|c|c|c|c|c|c|c|c|c|c|}
\hline & $\begin{array}{c}\text { Adjusted } \\
\mathrm{R}^{2}\end{array}$ & $\mathrm{~F}$ & \begin{tabular}{|c|}
$\begin{array}{c}\text { Number of } \\
\text { firm-trading } \\
\text { days }\end{array}$ \\
\end{tabular} & Intercept & REPURCH & VOLAT & VOLUME & SRD & MM \\
\hline \multicolumn{3}{|c|}{ Dependent variable } & \multicolumn{7}{|c|}{ DEPTH- first data available for the trading day } \\
\hline \multirow[t]{3}{*}{1} & $36.60 \%$ & 33291 & 173025 & 7.01 & -0.102 & -0.717 & 0.2258 & & \\
\hline & & $<.0001$ & & 704.28 & -15.92 & -89.79 & 301.57 & & \\
\hline & & & $\operatorname{Pr}>|t| \mid$ & $<.0001$ & $<.0001$ & $<.0001$ & $<.0001$ & & \\
\hline \multirow[t]{3}{*}{2} & $23.62 \%$ & 13379 & 173025 & 9.18 & -0.08 & -0.609 & & 1.23 & -0.206 \\
\hline & & $<.0001$ & & 1413.51 & -11.88 & -68.31 & & 192.46 & -24.96 \\
\hline & & & $\operatorname{Pr}>|t| \mid$ & $<0.0001$ & $<0.0001$ & $<0.0001$ & & $<0.0001$ & $<0.0001$ \\
\hline \multicolumn{3}{|c|}{ Dependent variable } & \multicolumn{7}{|c|}{ SPREAD- first data available for the trading day } \\
\hline \multirow[t]{3}{*}{3} & & & 173025 & 0.052 & 0.00275 & 0.0226 & -0.00359 & & \\
\hline & & $<.0001$ & & 207.75 & 17.10 & 112.93 & -191.13 & & \\
\hline & & & $\operatorname{Pr}>|t| \mid$ & $<.0001$ & $<.0001$ & $<.0001$ & $<.0001$ & & \\
\hline \multirow[t]{3}{*}{4} & $17.19 \%$ & 8978 & 173025 & 0.0134 & 0.00316 & 0.02284 & & -0.01592 & 0.01335 \\
\hline & & $<.0001$ & & 87.52 & 18.93 & 108.47 & & -105.55 & 68.36 \\
\hline & & & $\operatorname{Pr}>|t| \mid$ & $<0.0001$ & $<0.0001$ & $<0.0001$ & & $<0.0001$ & $<0.0001$ \\
\hline \multicolumn{3}{|c|}{ Dependent variable } & \multicolumn{7}{|c|}{ SPREAD- average of all spreads available for the trading day } \\
\hline \multirow[t]{3}{*}{5} & & & 173025 & 0.0485 & 0.0021 & 0.0194 & -0.0343 & & \\
\hline & & $<.0001$ & & 222.61 & 14.98 & 110.71 & -209.38 & & \\
\hline & & & $\operatorname{Pr}>|t| \mid$ & $<.0001$ & $<.0001$ & $<.0001$ & $<.0001$ & & \\
\hline \multirow[t]{3}{*}{6} & $20.20 \%$ & 10952 & 173025 & 0.01155 & 0.00255 & 0.01975 & & -0.01565 & 0.01431 \\
\hline & & $<.0001$ & & 86.58 & 17.57 & 107.78 & & -119.15 & 84.17 \\
\hline & & & $\operatorname{Pr}>|t|$ & $<0.0001$ & $<0.0001$ & $<0.0001$ & & $<0.0001$ & $<0.0001$ \\
\hline
\end{tabular}
p-values are reported, with t-statistics in italics. 


\section{Footnotes}

${ }^{1}$ The role of the AMF is similar to that of the Securities and Exchange Commission in the U.S.

${ }^{2}$ The reference period covers the three trading days before the repurchase for the most liquid shares, listed on the deferred settlement segment. For cash only shares, the reference period is 15 trading days before the repurchase date.

${ }^{3}$ Changes to the block trading rules were introduced in April 2003, and all shares are now eligible.

${ }^{4}$ Upstairs transactions can be executed through the Central Order Book or on the block trade facility, the choice being up to the investors.

${ }^{5}$ There are two explanations for this relatively large number of trades on a given day on the Paris market. One, any order quantity is accepted, even a quantity of 1 share, with no penalty applicable. Two, it is an agency market, where orders are automatically transferred from the investor and the grouping of trades by brokers is limited.

${ }^{6}$ As a robustness check on our results, we replicated all the calculations of Table 3 with an equally-weighted average price. The price calculation method (weighted or non-weighted) does not affect our results, which are essentially identical in both cases.

${ }^{7}$ As a robustness check, we also replicated the tests carried out by Brockman and Chung (2001) using a bootstrapping technique. For each program in the sample, we randomly generate 50,000 alternative repurchase plans, holding constant the repurchasing period, the number of repurchase days and the number of shares repurchased, and allow only the timing of the buyback to vary. For $37 \%$ of the repurchase programs, timing ability (bootstrapped costs higher than actual costs) is significant at the $5 \%$ level (compared to $37.3 \%$ in Brockman and Chung).

${ }^{8}$ All of our tests were also verified using multivariate analysis, using market type, volatility and number of trades possible in a session as control variables. The results confirm the univariate analysis.

${ }^{9}$ This analysis was also conducted with abnormal returns and the results are similar.

${ }^{10}$ The first available spreads generate similar results.

${ }^{11}$ Results are presented for the effective relative spread and depth at opening, and for the average relative daily spread, but other measures generate similar results.

${ }^{12}$ For a review of the determinants of bid-ask spreads, see Bollen, Smith and Whaley (2003). For a review of the market microstructure literature, see Stoll (2003).

${ }^{13}$ The results are not affected by inclusion of other volatility measures, including volatility calculated on the basis of hourly or quarter-hourly data, but these measures have the disadvantage of eliminating all stocks listed on the auction market.

${ }^{14}$ When the equations presented are estimated for the subsamples established by settlement and trading methods, the results regarding the repurchase variables remain identical. 